\title{
The Impact of Climate Change on Zooplankton Biodiversity Index (ZBDI) in Lake Kinneret, Israel
}

\author{
Moshe Gophen \\ Migal, Scientific Research Institute, Kiryat Shmone, Israel \\ Email: Gophen@Migal.org.il
}

How to cite this paper: Gophen, M. (2020) The Impact of Climate Change on Zooplankton Biodiversity Index (ZBDI) in Lake Kinneret, Israel. Open Journal of Ecology, 10, 822-828.

https://doi.org/10.4236/oje.2020.1012050

Received: November 22, 2020

Accepted: December 25, 2020

Published: December 28, 2020

Copyright $\odot 2020$ by author(s) and Scientific Research Publishing Inc. This work is licensed under the Creative Commons Attribution International License (CC BY 4.0).

http://creativecommons.org/licenses/by/4.0/

\section{(c) (i) Open Access}

\begin{abstract}
Climate change conditions were indicated in the watershed of Lake Kinneret: air and consequently water temperature increase, decline in rainfall, and diminish river discharges accompanied by a reduction in Epilimnetic nitrogen and a slight increase in phosphorus. It is suggested that warming trend of the Kinneret Epilimnion enhanced decline of Zooplankton Biodiversity Index (ZBDI).
\end{abstract}

\section{Keywords}

Climate Change, Kinneret, Zooplankton, Biodiversity

\section{Prefaced Background}

Evaluation of pollution processes in lakes are commonly, indicates changes of nutrients dynamics, phytoplankton biomass (density and composition) and physical properties such as water temperature, water level fluctuations and hydrological conditions. During the last 30 - 40 years, the involvement of fish community structure and feeding habits respectively were also included as factors of lakes pollution significances. The study of thermal pollution became recently an intensive research topic due to climate change, mostly global warming. A world-wide development of awareness to concern about water quality is indicated by major parameters such as biodiversity and biomass density of plankton organisms.

The Shannon-Wiener Biodiversity Index was implemented for the study of Zooplankton Bio-Diversity Index (BDI) in Lake Kinneret. Four, five and nine species of Copepoda, Cladocera and Rotifera, respectively, were included. Direct relations between Epilimnetic temperatures [1] and Zooplankton Bio-Diversity 
Indexes (BDI) were indicated: Matching was found between low BDI and the high summer temperature and between higher BDI and the low winter temperature. Lake Kinneret is a warm Monomictic body of freshwater located in the sub-tropical geographic zone which represents short, wet and cold winter whilst the summer is long, dry and warm [2]. Consequently, high degrees of seasonal temperature changes induce significantly seasonal BDI fluctuations. Since mid-1980's Regional Climate change of, among others, temperature elevation was documented in the Lake Kinneret (Figure 1 and Figure 2) drainage basin and consequently in the Kinneret Epilimnion (Figure 3) [1]. It is suggested that temperature increase probably enhanced the seasonal changes of BDI values. Moreover, progressive dryness conditions (Figure 4) induced Peridinium disappearance and promoted domination of Cyanobacteria in Lake Kinneret (Figure 5). The proliferation of Harmful Cyanobacteria (HFCB) is presently a global concern and the impact of temperature elevation is emphasized. Lake Kinneret is a prominent example of those global climate changes. The decline of precipitation, reduction of river discharges and temperature elevation were enhanced during the recent 25 Years.
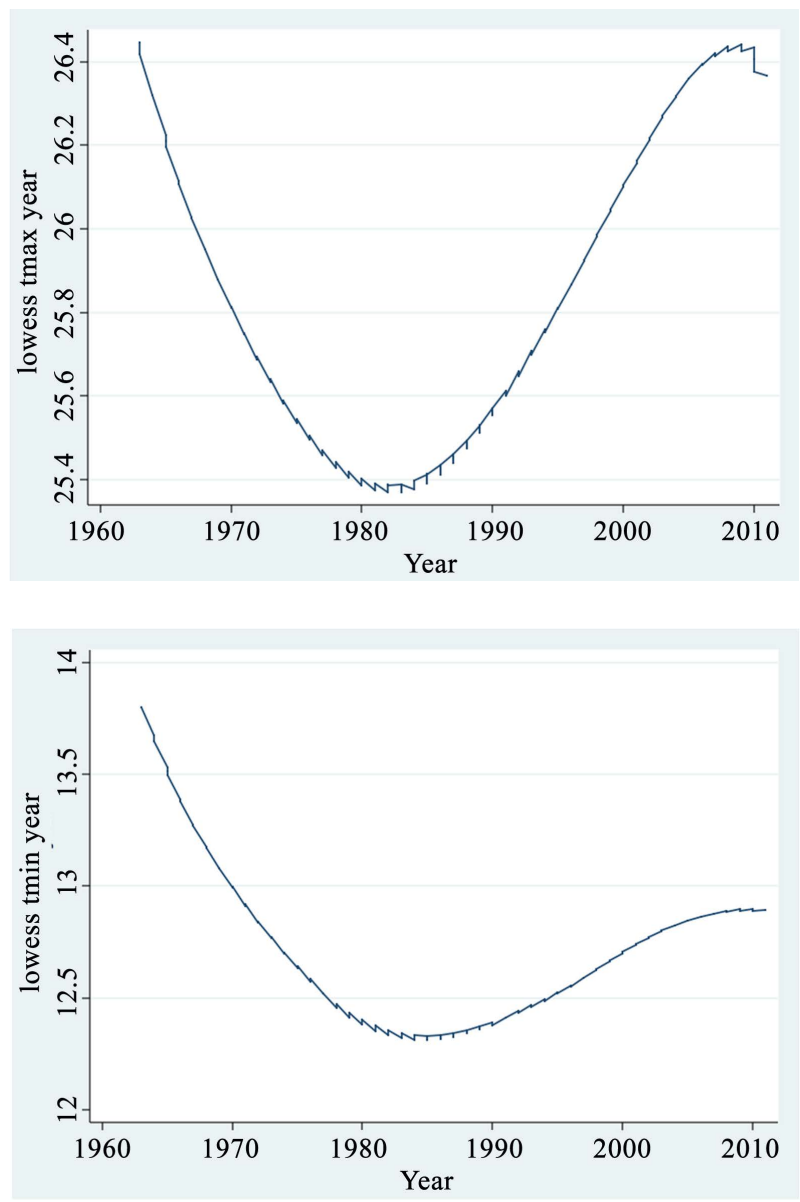

Figure 1. Trend of temporal (1963-2011) changes (LOWESS; 0.8) of annual averages of daily maxima (upper) and minima (lower) of air Temperatures in Dafna meteorological station In the Kinneret Watershed. 


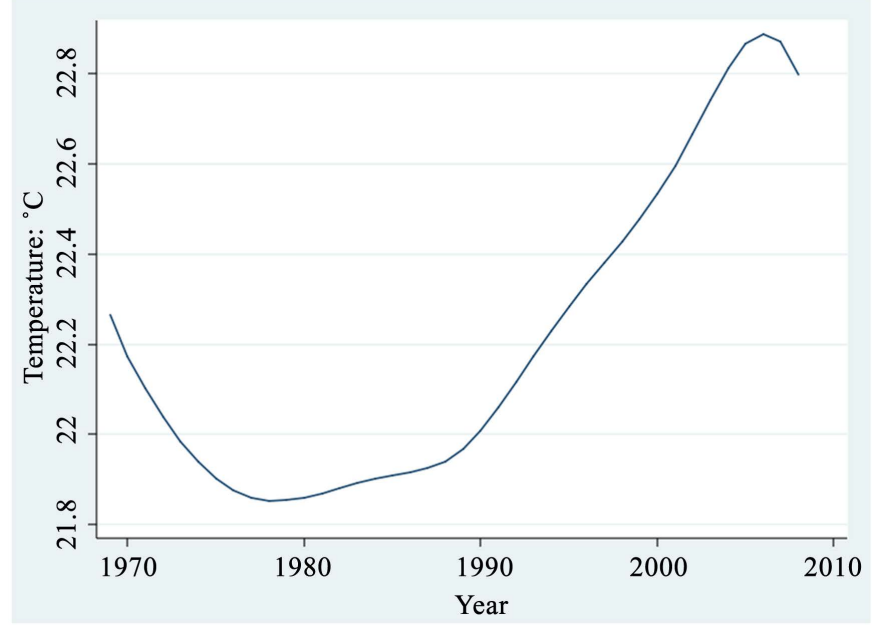

Figure 2. Trend of changes (LOWESS; 0.8) of annual means of whole water column averaged temperature in Lake Kinneret during 1969-2008.

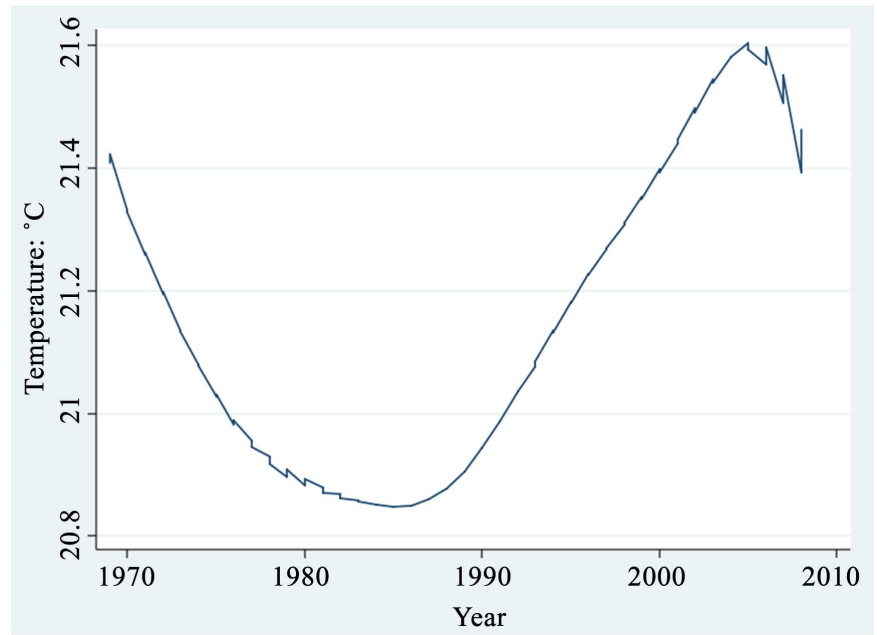

Figure 3. Trend of changes (LOWESS; 0.8) of annual means of the Epilimnioin layer averaged temperature in Lake Kinneret during 1969-2008.

Consequently, the influence of resulted Nitrogen input decline and water temperature increase enhanced the disappearance of the Peridinium phytoplankter domination which was replaced by toxic Cyanobacteria (HFCB) algal composition (Figure 5) [3].

\section{Results and Discussion}

\subsection{Climate Change Implication}

Heat capacity or thermal capacity, defined as the amount of heat energy that must be provided to an object (water mass) in order to raise its temperature by one unit. Heat capacity is proportional to the water mass volume. Heat capacity of a certain mass is divided by the weight or volume of the mass, yielding the specific heat capacity (or "specific heat"). The volumetric heat capacity indicates the heat capacity per volume. 

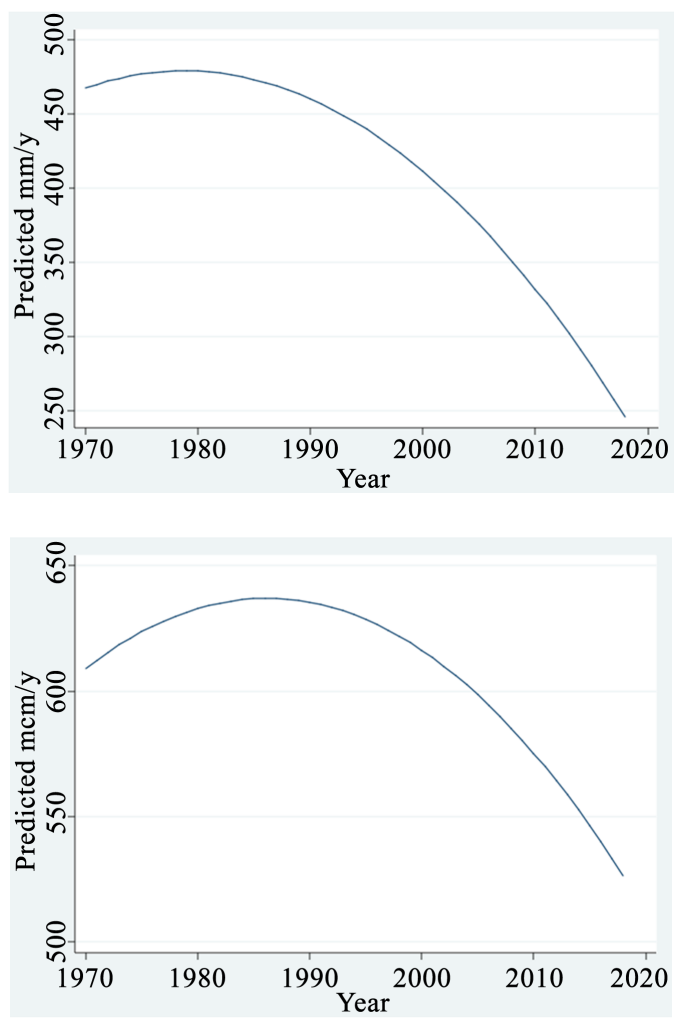

Figure 4. FP Regressions between annual rain ( $\mathrm{mm}$ ) (upper) and annual Jordan discharge $(\mathrm{mcm} / \mathrm{y})($ lower) and Years (1970-2010).
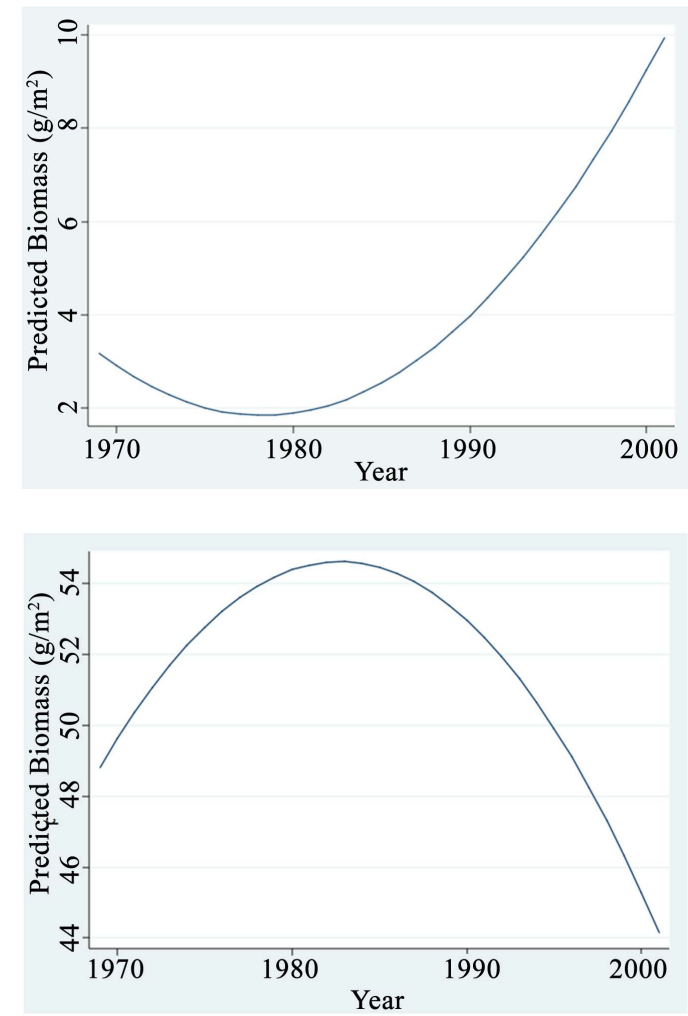

Figure 5. FP regressions between annual averages of phytoplankton biomass $\left(\mathrm{g} / \mathrm{m}^{2}\right)$ : Peridinium (upper) and Cyanobacteria (lower), and years (1970-2001). 
Data given in Table 1 indicates a typical reduction of Bathymetric layer volumes (Serruya 1978), and the increase of layer temperatures $(\Delta \mathrm{T})$ by $0.2^{\circ} \mathrm{C}-$ $0.4^{\circ} \mathrm{C}$ between 1969-2001.

The data given in Table 2 indicates the closely related changes of rain decline and air temperature increase.

\subsection{Climate Change and BDI Interrelationships}

There are many documentations about temperature causation for modification of the BDI's aimed at undermining ecosystems' stability. It was indicated that Climate change potentially drives Biodiversity patterns. The great level of dependence between Biodiversity and Temperature at the extreme nutrient level, confirmed the direct impact of Temperature and nutrients on Biodiversity. Consequently, future climate scenarios such as global warming could alter Biodiversity. The positive relations between temperature and species richness (Biodiversity) was widely documented.

Results in Table 3 indicate linear temporal significant relations between BDI and Years, and Temperature and Years; and also Significant relations between

Table 1. Bathymetrical depth layer volumes $\left(10^{6} \mathrm{~m}^{3}\right)$ and respective mean temperatures during two periods in Lake Kinneret: 1969-1980 (mean Water level 210.09 mbsl; mean lake volume $3834 \times 10^{6} \mathrm{~m}^{3}$ ) and 1991-2002 (mean Water Level $211.42 \mathrm{mbsl}$; mean lake volume $\left.2863 \times 10^{6} \mathrm{~m}^{3}\right)$ and periodical $\Delta \mathrm{T}\left({ }^{\circ} \mathrm{C}\right)$.

\begin{tabular}{cccccc}
\hline $\begin{array}{c}\text { Depth Layer } \\
(\mathrm{m})\end{array}$ & $\begin{array}{c}\text { Volume }\left(10^{6} \mathrm{~m}^{3}\right) \\
1969-1980\end{array}$ & $\begin{array}{c}\text { Volume }\left(10^{6} \mathrm{~m}^{3}\right) \\
1991-2002\end{array}$ & $\begin{array}{c}\text { Mean Temp. }\left({ }^{\circ} \mathrm{C}\right) \\
(1969-1980)\end{array}$ & $\begin{array}{c}\text { Mean Temp. }\left({ }^{\circ} \mathrm{C}\right) \\
(1991-2002)\end{array}$ & $\begin{array}{c}\Delta \mathrm{T} \\
\left({ }^{\circ} \mathrm{C}\right)\end{array}$ \\
\hline $0-10$ & 1573 & 1279 & 21.9 & 22.3 & 0.4 \\
$11-20$ & 1215 & 992 & 20.2 & 20.4 & 0.2 \\
$21-30$ & 729 & 506 & 16.3 & 16.7 & 0.4 \\
$31-40$ & 309 & 85 & 15.3 & 15.5 & 0.2 \\
\hline
\end{tabular}

Table 2. Periodical means of annual precipitations ( $\mathrm{mm})$, daily maximal and minimal air temperatures (Dafna station).

\begin{tabular}{cccc}
\hline Period & $\begin{array}{c}\text { Annual Precipitation } \\
(\mathrm{mm})\end{array}$ & $\begin{array}{c}\text { Daily Minimal air } \\
\text { temperature }\left({ }^{\circ} \mathrm{C}\right)\end{array}$ & $\begin{array}{c}\text { Daily Mximal air } \\
\text { temperature }\left({ }^{\circ} \mathrm{C}\right)\end{array}$ \\
\hline $1969-1980$ & 657 & 12.6 & 25.6 \\
$1981-1990$ & 617 & 11.8 & 25.0 \\
$1991-2001$ & 604 & 12.8 & 26.0 \\
\hline
\end{tabular}

Table 3. Linear regression parameters $\left(\mathrm{r}^{2}, p\right)$ between epilimnetic Temperature (annual mean) (Tem.), Time (year), Annual mean Index of Diversity (Index), annual mean of Total zooplankton densities (No/L) (Total) during 1970-2001, $\mathrm{S}=$ Significant $(p<0.1)$.

\begin{tabular}{ccc}
\hline Regression & $\mathrm{r}^{2}$ & $p$ \\
\hline Tem Vs Year & 0.307 & $0.001(\mathrm{~S})$ \\
Index Vs Year & 0.525 & $<0.0001(\mathrm{~S})$ \\
Index Vs Tem & 0.180 & $0.015(\mathrm{~S})$ \\
Total Vs Year & 0.141 & $0.034(\mathrm{~S})$ \\
Total Vs Index & 0.272 & $0.002(\mathrm{~S})$ \\
\hline
\end{tabular}


BDI and Temperature, and Total zoolnkton [4]. The BDI is a measure of biological diversity which is an indicator of species richness in a habitat diverted. It was fairly accepted that the dominant parameter effect on the BDI changes is temperature. Global Biodiversity expressed as the richness of families, genera, species and sub-species is significantly affected by temperature. The decline of BDI in response to warm "greenhouse" phases which may have implications for biological extinctions and Biodiversity changes under future global warming events is also known. An important conclusion documented in a UN report on loss of Biodiversity and extinctions is that the severe threat to species richness and elimination is significantly affected by climate change and the decline of the index is clearly related to temperature elevation. BDI is affected by temperature but the significance of this impact depends on the time span continuation and/or the thermal range of the modification. If high and low thermal conditions alternate, BDI fluctuates intermittently as well. It was indicated that seasonal fluctuations of epilimnetic temperature are consequently accompanied by a significant change of BDI level. Therefore, it is suggested that BDI monitoring in the Kinneret Epilimnion supports an indication of Global Warming effect in this part of the planet.

Air temperature elevation causes warmer lake surface waters which in turn increase stratification stability due to increase water density gradient profoundly. Reduction in bottom-up fluxed nutrient migration is possibly enhanced. Decline of rainfall could be the reason for longer residence time following by nutrients accumulation a well known cause of pollution and water quality deterioration. Moreover, bloom forming Cyanobacteria are likely to be favored in a warming climate [5] [6] [7]. It was reported that in the last century temperature increased by approximately $0.7^{\circ} \mathrm{C}$ and continuation is likely to be elevated by $1^{\circ} \mathrm{C}-6^{\circ} \mathrm{C}$ by the end of the 21 st century.

\section{Summary}

The climate change (rainfall decline) induced lowering of external nutrient inputs (mostly Nitrogen) whilst internal factors of volume shrinkage and possibly internal conditions enhanced Phosphorus release from the sediments. Consequently, the thermal pollution (Temperature increase) driven eco-forces enforced a combined effect between the external (climate condition) and internal conditions (enhanced $\mathrm{P}$ release from the sediments) and resulted in a water quality deterioration. Moreover, global warming caused an increase of extinction risk, i.e. BDI decline [8]. Climate change acts as addittional pressure compromising Biodiversity and freshwater ecosystem function and potentially disturbing the ecological services they provide [9]. Increase of diversity in response to minor decline of temperature in a warm deep sea was documented by [10].

\section{Conflicts of Interest}

The author declares no conflicts of interest regarding the publication of this paper. 


\section{References}

[1] LKDB (1970-2018) Kinneret Limnological Laboratory, Annual Reports.

[2] Serruya, C .(ed.) (1978) Lake Kinneret. Monographiae Biologicae, 32, 501 p. https://doi.org/10.1007/978-94-009-9954-1

[3] Zohary, T., Sukenik, A., Berman, T. and Nishri, A. (Eds.) (2014) Lake Kinneret: Ecology and Management. Aquatic Ecology, 6, 683 p. https://doi.org/10.1007/978-94-017-8944-8

[4] Gophen, M. (2019) The Ecological Outcome of Climate Change in Lake Kinneret-Thermal Pollution. Open Journal of Modern Hydrology, 9, 89-102. https://doi.org/10.4236/ojmh.2019.93005

[5] Vincent, W.F. (2010) Chapter: Effects of Climate Change in Lakes. In: Likens, G.E., Ed., Lake Ecosystem Ecology: A Global Perspective, A Derivative of Encyclopedia of Inland Waters, Academic Press, Cambridge, Massachusetts, 65-70.

[6] IPCC (2007) Fourth Assessment Report: Synthesis Report AR4 Climate Change: Synthesis Report. Working Group Report: The Physical Science Basis, 989-996.

[7] Mackay, A.W., Ryves, D.B., Morley, D.W., Jewson, D.H. and Rioual, P. (2006) Assessing the Vulnerability of Endemic Diatom Species in Lake Baikal to Predicted Future Climate Change: A Multivariate Approach. Global Change Biology, 12, 2297-2315. https://doi.org/10.1111/j.1365-2486.2006.01270.x

[8] Gophen, M. (2018) Temperature Impact on the Shnnon-Wiener Biodiversity Index (BDI) of Zooplankton in Lake Kinneret. Open Journal of Modern Hydrology, 8, 39-49. https://doi.org/10.4236/ojmh.2018.82004

[9] Thomas, C.D., et al. (18 Co-Authors) (2004) Extinction Risk from Climate Change. Nature, 427, 145-147.

[10] Danovaro, R. and Pasceddu, A. (2004) Biodiversity Response to Climate Change in a Deep Sea. Ecology Letters, 7, 821-828.

https://doi.org/10.1111/j.1461-0248.2004.00634.x 